International Journal of Agricultural Science and Research (IJASR)

ISSN (P): 2250-0057; ISSN (E): 2321-0087

Vol. 10, Issue 6, Dec 2020, 99-104

(C) TJPRC Pvt. Ltd.

\title{
ECONOMIC ANALYSIS OF CAPSICUM UNDER PROTECTED CULTIVATION IN KRISHNAGIRI DISTRICT OF TAMILNADU
}

\author{
S S LAKSHMIPATHY ${ }^{1} \&$ N DEEPA ${ }^{2}$ \\ ${ }^{1} P G$ Scholar, Department of agricultural and rural management, Tamil Nadu Agricultural University, Coimbatore, Tamil \\ Nadu, India \\ ${ }^{2}$ Assistant Professor, Department of agricultural and rural management, Tamil Nadu Agricultural University, Coimbatore,
}

Tamil Nadu, India

\section{ABSTRACT}

Protected cultivation is booming in the world to produce high quality and valuable horticultural crops. In India the protected cultivation is done on the area of 2.15 lakhs ha from 2005-06 to 2017-18. Capsicum is one of the most popular vegetable crops in India. In India, production of capsicum found to be around 326 thousand tons from the area of 46 thousand hectare with the productivity of $7,108.70 \mathrm{~kg}$ per hectare during the year of 2017. In Tamil Nadu the total production of capsicum is around 16,689 tonnes from 284 hectare contributing 5.13 per cent of the total Indian production of capsicum during the year of 2017-2018. In Tamil Nadu Krishnagiri district stands first in the production with 16,310 tonnes (97.73 per cent) from the area of 268.64 hectare during the year of 2017-2018. So, the present study was used to study the economic analysis of capsicum under protected condition in Krishnagiri district of TamilNadu. Total investment of Rs.32,32,500 was used for constructing one acre of polyhouse. 50 per cent subsidy is availed for the farmers through National Horticultural Mission under Mission on Integrated Development of Horticulture Mission.In percentage analysis the polyhouse structure and erection were the major cost incurred with 71.15 per cent followed by polythene sheet and Insect proof net with 14.31 per cent. The total working capital for an acre of capsicum crop was found to be Rs.9,13, 432. Among the working capital, hired human Labour contributed 15.73 per cent of the total cost A1 which accounts for 59.88 per cent of the total cost of cultivation. The net present value at 12 per cent discount rate for three years was Rs.6,50,719 per acre of polyhouse area. The benefit cost ratio was 1.12 and internal rate of return is 36.20 per cent which shows the production of capsicum under protected condition is feasible.

KEYWORDS: Protected cultivation, Capsicum, Production, Investment, Cost of Cultivation

Received: Dec 09, 2020; Accepted: Dec 29, 2020; Published: Jan 13, 2021; Paper Id.: IJASRDEC202013

\section{INTRODUCTION}

Protected cultivation is growing of high value crops throughout the year by using protected structure by controlling wind, temperature, rainfall, insects and diseases through automatic, semi-automatic and manual system. In world scenario, there are more than 50 countries are into polyhouse cultivation. USA, Spain, Canada and The Netherlands stand top in the protected cultivation area. In Asia, China and Japan are the largest users of protected cultivation. Protected cultivation increases the income to farmers because of off season cultivation when compared to normal season. In northern plains of India, off season cultivation is most profitable technology (Nair et al 2014). During winter and spring, the polyhouse provides protective covering for successful production of off-season vegetables like summer squash. (Singh et al 2020). Protected cultivation showsprogress with liberalized economy and invention of newer technologies. It is not only creating avenues but also growers with fragmented land holdings show higher 
productivity level which retain economic relevance to agriculture (Sabir et al 2013). Vegetables cultivation under Protected condition offers best in quality, productivity and market price. Protected cultivators increase their income by growing off season vegetables (Singh b 2006)

Capsicum is one of the most popular vegetable crops in India. It is also known as bell pepper, Shimla mirch and sweet pepper. It is grown throughout the year under protected condition. Mostly the coloured capsicum is grown under polyhouse while green capsicum is grown in open field and shade net conditions. The demand for coloured capsicum is high in urban market because of hotel industry. Under protected condition the average yield per hectare is about 80-100 tonnes. In India, production of capsicum found to be around 326 thousand tons from the area of 46 thousand hectare with the productivity of 7,108.70 $\mathrm{kg}$ per hectare during the year of 2017.In Tamil Nadu the total production of capsicum is around 16,689 tonnes from 284 hectare contributing 5.13 per cent of the total Indian production of capsicum during the year of 2017-2018.InTamil Nadu Krishnagiri district stands first in the production with 16,310 tonnes (97.73 per cent) from the area of 268.64 hectare during the year of 2017-2018.So, the present study was used to study the economic analysis of capsicum under protected condition in Krishnagiri district of TamilNadu.

\section{OBJECTIVE}

1. Economic and feasibility analysis of capsicum under protected condition in Krishnagiri district of TamilNadu

\section{MATERIALS AND METHOD}

The study was conducted for production of capsicum under medium cost polyhouse at Krishnagiri district of TamilNadu during the year 2019-2020.To examine the economic analysis of capsicum production a well-structured interview schedule was prepared to collect the data at farm level. The multistage purposive sampling technique was used to select the sample respondents. The taluks and blocks are selected based on the area of production under capsicum in Krishnagiri district. Denkanikottai and Hosur taluks were selected. Four blocks namely Thalli, Denkanikottai, Hosur and Shoolagiri were selected. Beneficiaries list was collected from Horticulture Department and the data was collected from them. Ninety subsidy benefited farmers from the two taluks were selected randomly for the study. The establishment cost of polyhouse was calculated by using costing methods for an average size of one acre of polyhouse. Cost of cultivation was found out by using cost concepts which was given by Government of India through Commission on Agricultural Cost and Prices. Feasibility of capsicum production under protected condition was found out by using discounted and undiscounted measures like Net Present Value, Payback period, Benefit Cost Ratio and Internal Rate of Return. The study was completely based on the primary data collected from farmers during 2020.

\section{RESULTS AND DISCUSSIONS}

\section{Cost of Establishment}

Thepolyhouse investments are highly cost intensive during the first year. The details regarding establishment cost of polyhouse were given in the Table 1

Total investment of Rs. 3232500 was used for constructing one acre of polyhouse. 50 per cent subsidy is availed for the farmers through National Horticultural Mission under Mission on Mission (NHM) under the Mission on Integrated Development Horticulture (MIDH), Government of India, through the State Horticultural Department. The various costs involved in polyhouse construction are Greenhouse structure and erection, foundation pipe, land levelling, polythene sheet 
and insect net, irrigation system, sprayers and equipment. In percentage analysis the Polyhouse structure and erection was the major cost incurred with 71.15 per cent followed by polythene sheet and Insect proof net with 14.31 per cent. Irrigation system, foundation pipe and land levelling are contributing with 7.42 per cent,4.64 per cent and 1.55 per cent respectively.

\section{Cost of Cultivation}

The various cost concepts are used to find out the cost of cultivation of capsicum by using the method given by commission on agricultural cost and price CACP, Government of India. The cost of cultivation for one acre of capsicum crop isgiven in the Table 2. The total working capital for an acre of capsicum crop was found to be Rs.9,13,432. Among the working capital, hired human Labour contributed 15.73 per cent of the total cost A1 which 59.88 per cent of the total cost of cultivation. Seedlings, farm yard manure and plant protection are the various cost are the major contributors in cost A1.The cost B includes rental value and interest on fixed capital was found to be Rs.13,14,732. The imputed value of labour is Rs.72,000 (4.72 per cent). The total cost C3 was Rs. 1525405.2. Average yield is about 39,000 kg.with price of Rs.60. So, the gross income is about Rs. 23,40,000.By deducting gross return from total cost, the net income was Rs.8,14,595.

\section{Costs and Returns of Capsicum}

Cash inflow and outflow are calculated for capsicum production for first three years. The first-year cost data was collected directly from farmers and for remaining years the cost is increased 10 per cent of previous year. It takes one year for construction of polyhouse so in first year only fixed cost is taken and deducted from subsidy amount. The cost and returns of capsicum are given in the table 3

\section{Financial Analysis}

The financial feasibility is analysed by using discounted measures. The indicators such as NPV, BCR and IRR. The net present value at 12 per cent discount rate for three years was Rs.650719 per acre of polyhouse area. The benefit cost ratio was 1.12 and internal rate of return is 36.20 per cent which shows the production of capsicum under protected condition is feasible one.

Table 1: Establishment cost of polyhouse (1 acre)

\begin{tabular}{|c|l|c|c|}
\hline S. No & \multicolumn{1}{|c|}{ Particulars } & Amount & Percentage \\
\hline 1 & Land levelling & 50000 & 1.55 \\
\hline 2 & Sim or Foundation Pipe & 150000 & 4.64 \\
\hline 3 & Greenhouse Structure \& Erection & 2300000 & 71.15 \\
\hline 4 & Polysheet and Insect net & 462500 & 14.31 \\
\hline 5 & Irrigation System (Fertigation and drip) & 240000 & 7.42 \\
\hline 6 & Sprayers and Equipment & 25000 & 0.77 \\
\hline 7 & Others & 5000 & 0.15 \\
\hline & Total establishment cost & $\mathbf{3 2 3 2 5 0 0}$ & $\mathbf{1 0 0 . 0 0}$ \\
\hline 8 & NHM subsidy @Rs.435 per sq.m. & 1740000 & \\
\hline
\end{tabular}

Table 2: Cost of Cultivation

\begin{tabular}{|c|l|c|c|}
\hline S. No & \multicolumn{1}{|c|}{ Particulars } & Amount & Percentage \\
\hline 1 & Land preparation & 18000 & 1.18 \\
\hline 2 & Bed preparation & 5000 & 12.82 \\
\hline
\end{tabular}




\begin{tabular}{|c|l|c|c|}
\hline 3 & FYM & 92000 & 6.03 \\
\hline 4 & Mulching & 15600 & 0.67 \\
\hline 5 & Seedlings cost & 96000 & 6.29 \\
\hline 6 & Training material & 5000 & 0.33 \\
\hline 7 & Plant protection & 60000 & 3.93 \\
\hline 8 & Fertilizer & 20000 & 1.31 \\
\hline 9 & Hired human labour & 240000 & 15.73 \\
\hline 10 & Polyhouse Maintenance & 5000 & 0.33 \\
\hline 11 & Interest on working capital @ 7\% & 38962 & 2.55 \\
\hline 12 & Depreciation on fixed capital & 317750 & 20.83 \\
\hline 13 & Land revenue & 120 & 0.01 \\
\hline A & Cost A1 & $\mathbf{9 1 3 4 3 2}$ & $\mathbf{5 9 . 8 8}$ \\
\hline 14 & Interest on owned capital (excluding land) @ 12\% & 381300 & 25.00 \\
\hline B & Cost B1 & 1294732 & $\mathbf{8 4 . 8 8}$ \\
\hline 15 & Rental value of owned land & 20000 & 1.31 \\
\hline C & Cost B2 & 1314732 & $\mathbf{8 6 . 1 9}$ \\
\hline 16 & Imputed value of family Labour & 72000 & 4.72 \\
\hline D & Cost C1(Cost B1+ Imputed value of family Labour) & 1366732 & 89.60 \\
\hline E & Cost C2(Cost B2+ Imputed value of family Labour) & 1386732 & $\mathbf{9 0 . 9 1}$ \\
\hline F & Cost C3(cost c2+10\% of c2) as management cost & $\mathbf{1 5 2 5 4 0 5 . 2}$ & $\mathbf{1 0 0 . 0 0}$ \\
\hline 17 & Average yield (Kg/4000 m2) & 39000 & \\
\hline 18 & Average output price (Rs/Kg) & 60 & \\
\hline 19 & Gross return & & \\
\hline & & $\mathbf{2 3 4 0 0 0 0}$ & \\
\hline
\end{tabular}

Table 3: Cost and Returns

\begin{tabular}{|c|c|c|c|c|c|c|c|c|}
\hline Year & Total Cost & $\begin{array}{c}\text { Total } \\
\text { Benefit }\end{array}$ & $\underline{\text { DF@12\% }}$ & $\begin{array}{c}\text { Disc.Cost } \\
\text { (a) } 12 \%\end{array}$ & $\begin{array}{c}\text { Disc.Benefit } \\
\text { (a) } 12 \%\end{array}$ & $\underline{\text { DF@40\% }}$ & $\begin{array}{c}\text { Disc.Cost } \\
\text { (a) } 40 \%\end{array}$ & $\begin{array}{c}\text { Disc.Benefit } \\
\text { (a) } 40 \%\end{array}$ \\
\hline 0 & 1492500 & 0 & 1.00 & 1492500 & 0 & 1 & 1492500 & 0 \\
\hline 1 & 1525405 & 2340000 & 0.89 & 1361969 & 2089286 & 0.71 & 1083038 & 1661400 \\
\hline 2 & 1677946 & 2574000 & 0.80 & 1337648 & 2051977 & 0.51 & 855752 & 1312740 \\
\hline 3 & 1845740 & 2831400 & 0.71 & 1313761 & 2015335 & 0.36 & 664467 & 1019304 \\
\hline \multicolumn{4}{|l|}{ Total } & 5505878 & 6156597 & & 4095757 & 3993444 \\
\hline
\end{tabular}

Table 4: Financial analysis

\begin{tabular}{|l|l|l|}
\hline \multicolumn{1}{|c|}{ S. No } & \multicolumn{1}{|c|}{ Economic indicator } & \multicolumn{1}{c|}{ Particulars } \\
\hline 1 & Net Present Value & $\mathbf{6 5 0 7 1 9}$ \\
\hline 2 & Benefit Cost Ratio & $\mathbf{1 . 1 2}$ \\
\hline 3 & Internal Rate Return & $\mathbf{3 6 . 2 0} \%$ \\
\hline
\end{tabular}

\section{REFERENCES}

1. Nair, R., \& Barche, S. (2014). Protected cultivation of vegetables-present status and future prospects in India. Indian J. Appl. Res, 4(6), 245-247. 
2. Patel, JISNU K., K. S. Jadav, and H. C. Parmar. "An analysis of resource use efficiency of drip and conventional chilli farm in middle Gujarat." International Journal of Humanities and Social Sciences, 3 (3), 8591 (2014).

3. Prakash, P., Kumar, P., Kar, A., Singh, A. K., \& Anbukkani, P. (2019). Progress and Performance of Protected Cultivation in Maharashtra. Indian Journal of Economics and Development, 15(4), 555-563.

4. Senthilkumar S., K. R. Ashok, M. Chinnadurai and Ramanathan S. P. 2018. An Economic Analysis of Capsicum Production under Protected Cultivation in North West Region of Tamil Nadu, India. Int.J.Curr.Microbiol.App.Sci. 7(06): 2276-2283.

5. Olaniyan, O. S., and V. O. Ajileye. "STRENGTH CHARACTERISTICS OF LATERITIC SOIL STABILIZED WITH TERRASIL AND ZYCOBOND NANNO CHEMICALS." International Journal of Civil Engineering (IJCE)7.2, Feb - Mar 2018; 1 - 12

6. Singh S, Saxena AK (2020) Protected Cultivation of Summer Squash in Mid-hills of Uttarakhand. J Hortic Sci Res $3(1): 82-85$.

7. Lego, M. U. M. T. A. K., D. E. V. I. Singh, and S. O. Y. I. N. G. B. E. N. I. Tsanglao. "Effect of different levels of NPK on growth, yield and economic of capsicum (Capsicum annuum l.) cv. asha under shade net house cultivation." Int. J. Agric. Sci. Res 6.4 (2016): 5-8.

8. Singh, B. and Sirohi, N.P.S. (2006). PROTECTED CULTIVATION OF VEGETABLES IN INDIA: PROBLEMS AND FUTURE PROSPECTS. Acta Hortic. 710, 339-342

9. Kumari, S. SURYA, et al. "Genetic divergence and combining ability studies for exploitation of heterosis in paprika (Capsicum annuum L)." International journal of agricultural science and research 4.2 (2014): 59-66.

10. Agarwal, Priti, et al. "Green synthesis of silver nanoparticles using callus extract of Capsicum annuum L. and their activity against microorganisms." International journal of nanotechnology and application 4.5 (2014): 1-8. 

